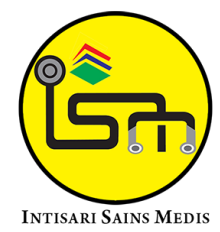

Published by Intisari Sains Medis

\section{Hubungan ASI eksklusif dengan angka kejadian diare pada anak usia 6 - 24 bulan di RSUD Wangaya}

\author{
Andrew Permana Suliarta ${ }^{1 *}$, I Wayan Bikin Suryawan ${ }^{1}$, \\ Anak Agung Made Sucipta ${ }^{1}$
}

'Bagian/SMF IImu Kesehatan Anak RSUD Wangaya, Denpasar, Bali, Indonesia

\section{*Korespondensi to:}

Andrew Permana Suliarta; Bagian/SMF IImu Kesehatan Anak RSUD Wangaya, Denpasar, Bali, Indonesia;

andrew.suliarta@gmail.com

\section{Diterima: 25-04-2021}

Disetujui: 20-08-2021

Diterbitkan: 31-08-2021

\title{
ABSTRACT
}

Background: Diarrhea is a gastrointestinal tract disease with the highest incidence rate and the most common cause of death in children under five years old. Based on Riskesdas 2013, the prevalence of diarrhoea in Indonesia is between $1-4$ years old. Diarrhea is particularly common in developing countries due to inadequate sanitation and hygiene, including a lack of safe, clean water for drinking and a lack of concern for nutrition and overall health. The risk of diarrhoea in children is also influenced by the pattern of breastfeeding. Exclusive breastfeeding in infants is known to protect the babies against diarrhea.

Methods: This is an observational study where the data was collected from inpatient medical records between January - December 2019. This study was conducted analytically using a retrospective crosssectional design. For sampling, a systematic random sampling technique was used. In this study, univariate analysis was used to get the distribution and the proportion of each variable. The relationship between

Keywords: Exclusive breastfeeding, diarrhea, children age 6 - 24 months Cite This Article: Suliarta, A.P., Suryawan, I.W.B., Sucipta, A.A.M. 2021. Hubungan ASI eksklusif dengan angka kejadian diare pada anak usia 6 - 24 bulan di RSUD Wangaya. Intisari Sains Medis 12(2): 700-704. D0I: 10.15562/ ism.v12i2.1032

\section{ABSTRAK}

Latar Belakang: Diare adalah salah satu penyakit sistem pencernaan yang memiliki angka kejadian tertinggi dan paling sering menyebabkan kematian pada anak berusia dibawah lima tahun. Faktor risiko diare pada anak juga dipengaruhi oleh pola pemberian ASI eksklusif. ASI eksklusif diketahui memiliki efek perlindungan pada bayi terhadap diare. Penelitian ini bertujuan untuk membuktikan adanya hubungan antara pemberian ASI eksklusif dengan angka kejadian diare pada anak usia 6 - 24 bulan.

Metode: Penelitian ini merupakan penelitian exclusive breastfeeding and the incidence of diarrhea was analyzed using chi-square. Statistical analysis was performed in a 95\% coefficient interval (alpha $=0.05$ ). Results: Fifty-six patients were enrolled after meeting the inclusion criteria; $58.3 \%$ are male. The number of children who had diarrhea was 36 (64.3\%), from that number $38.9 \%$ are aged 6 to 12 months, and $61.1 \%$ are aged 13 to 24 months. Children who have received exclusive breastfeeding were 22 children (39.3\%). There is a relationship between exclusive breastfeeding to the incidence rate of diarrhea in children aged $6-24$ months $(p=0.003)$. To determine the relative risk estimation using prevalence ratio (RP), with the study calculation obtained $0.51(<1)$.

Conclusion: There is a significant relationship between exclusive breastfeeding and the incidence of diarrhea in children aged 6-24 months. The prevalence ratio results in 0.51 it tells that exclusive breastfeeding is a protective factor against diarrhea. 
square. Analitik yang dilakukan menggunakan interval kepercayaan 95\% (alpha =0,05).

Hasil: Terdapat lima puluh enam sampel yang memenuhi kriteria inklusi, 58,3\% diantaranya adalah laki-laki. Angka kejadian diare yang terjadi pada anak sebanyak 36 (64,3\%), dari angka tersebut 38,9\% berusia 6 - 12 bulan dan $61,1 \%$ berusia $13-24$ bulan. Anak yang mendapat ASI eksklusif sebanyak 22 anak (39,3\%). Dari hasil penelitian ini didapatkan hubungan antara ASI Eksklusif dengan angka kejadian diare pada anak usia $6-24$ bulan $(p=0,003)$. Rasio prevalensi pada penelitian ini didapatkan sebesar $0,51(<1)$.

Kesimpulan: Terdapat hubungan yg signifikan antara ASI eksklusif dengan angka kejadian diare pada anak usia 6 - 24 bulan. Dari hasil rasio prevalensi 0,51, menunjukkan bahwa anak yang mendapatkan ASI eksklusif memiliki risiko mengalami diare lebih rendah yaitu 0,51 kali apabila dibandingkan dengan anak yang tidak mendapat ASI eksklusif.

Kata kunci: ASI eksklusif, diare, anak usia 6 - 24 bulan

Sitasi Artikel ini: Suliarta, A.P., Suryawan, I.W.B., Sucipta, A.A.M. 2021. Hubungan ASI eksklusif dengan angka kejadian diare pada anak usia 6 - 24 bulan di RSUD Wangaya. Intisari Sains Medis 12(2): 700-704. D0I: 10.15562/ ism.v12i2.1032

\section{PENDAHULUAN}

Diare merupakan penyakit gangguan saluran pencernaan yang paling sering terjadi dan menjadi penyebab kematian utama pada balita di dunia. Berdasarkan data WHO tahun 2017, diare merupakan penyebabkan morbiditas dan mortalitas terbesar ke-2 pada balita. ${ }^{1}$ Secara global insiden diare pada balita mencapai 1,7 miliar kasus setiap tahunnya. Setiap tahun diare membunuh sekitar 525.000 anak dibawah 5 tahun. ${ }^{1}$ Berdasarkan Riskesdas tahun 2013 prevalensi diare di Indonesia terbayak pada usia $1-4$ tahun. ${ }^{2}$ Di Indonesia diare masih merupakan penyebab utama kematian bayi $(31,4 \%){ }^{3}$ Berdasarkan profil Riskesdas tahun 2018 angka kejadian diare pada balita di Bali adalah $10 \%{ }^{4}$ Diare sendiri menempati urutan pertama dari 3 kasus penyakit anak terbanyak yang dirawat di RSUD Wangaya. Kelompok umur kasus diare terbanyak pada balita usia 6 bln - 5 tahun.

Diare adalah suatu perubahan konsistensi feses menjadi lembek atau cair, bahkan dapat berupa air saja dan frekuensinya $\geq 3 \mathrm{x}$ dalam satu hari. ${ }^{1}$ Berdasarakan waktu atau lamanya diare dibagi menjadi 2 yaitu diare akut dan diare kronis. Diare akut adalah terjadinya perubahan konsistensi feses menjadi lembek atau cair dengan frekuensi $\geq 3 \mathrm{x}$ dalam satu hari, yang berlangsung kurang dari 14 hari. Sedangkan diare kronik adalah terjadinya perubahan konsistensi feses menjadi lembek atau cair dengan frekuensi $\geq 3 \mathrm{x}$ dalam satu hari, yang berlangsung lebih dari 14 hari. ${ }^{5}$ Diare merupakan gangguan yang sering kali terjadi jika terdapat infeksi di saluran usus, yang biasanya disebabkan oleh berbagai jenis bakteria, virus, dan parasit. Patogen tersering yang menyebabkan infeksi tersebut adalah Rotavirus, Astrovirus, Calicivirus, Campylobacter, Shigella, Giardia, dan Entamoeba hystolitica. Selain itu diare bisa juga disebabkan oleh alergi makanan, keracunan makanan, dan penggunaan antibiotika. ${ }^{1,6}$

Diare terutama sering terjadi pada negara berkembang. Penyebabnya adalah karena sanitasi dan kebersihan yang tidak memadai, termasuk kurangnya air bersih yang aman untuk diminum, serta kurangnya kepedulian akan gizi dan kesehatan secara menyeluruh. ${ }^{7}$ Risiko diare pada anak juga dipengaruhi oleh pola pemberian ASI, dimana anak yang diberikan ASI eksklusif memiliki risiko lebih rendah terkena infeksi gastrointestinal dibanding anak yang hanya mendapat ASI selama 3-4 bulan. ${ }^{8}$

Air Susu Ibu (ASI) merupakan makanan yang ideal untuk bayi pada 6 bulan pertama kehidupan. Bayi dikategorikan mendapat ASI eksklusif jika bayi mendapat air susu ibu selama 6 bulan tanpa tambahan cairan lain, seperti susu formula, jeruk, madu, air teh, dan air putih, serta tanpa tambahan makanan padat, seperti pisang, bubur susu, biskuit, bubur nasi, dan nasi tim, kecuali vitamin dan mineral dan obat. ASI juga memberikan proteksi terhadap diare dan pneumonia. ${ }^{9}$ ASI memiliki sangat banyak manfaat untuk kesehatan dan perkembangan bayi. Protein, karbohidrat, dan lemak merupakan komponen utama dalam ASI. Selain itu ASI juga mengandung IgA, IgM, vitamin A, vitamin $\mathrm{D}$, vitamin $\mathrm{B} 6$, kalsium, besi, dan zink. ${ }^{10}$ Menurut penelitian ASI berperan memberikan proteksi terhadap infeksi melalui kandungan nukleotida yang dapat memicu kerja dari sistem imunitas tubuh. ASI terdapat juga oligosakarida yang merangsang pertumbuhan Laktobasilus bifidus yang meningkatkan keasaman traktus digestivus dan menghambat pertumbuhan kuman patogen. ${ }^{11,12}$

Berdasarkan hal tersebut diatas, perlu diteliti hubungan antara hubungan ASI eksklusif dengan angka kejadian diare pada anak usia 6-24 bulan di RSUD Wangaya. Penelitian dilakukan di RSUD Wangaya karena rumah sakit tersebut merupakan rumah sakit tipe B yang merupakan pusat rujukan dari banyak rumah sakit tipe $C$ yang berada di Kota Denpasar.

\section{METODE}

Penelitian ini merupakan studi observasional analitik dengan rancangan studi potong lintang (cross-sectional) dimana metode yang digunakan dalam penelitian ini adalah uji diagnostik untuk menilai sensitivitas, spesifisitas, nilai 
prediksi positif, nilai prediksi negatif, dan prevalensi, serta akurasi dari mean platelet volume untuk mendiagnosis sepsis neonatorum bila dibandingkan dengan diagnosis menggunakan kriteria diagnosis sepsis neonatorum menurut Panduan Praktik Klinis (PPK) Ilmu Kesehatan Anak RSUD Wangaya tahun 2018. Penelitian ini dilaksanakan di Ruang Perinatologi RSUD Wangaya Denpasar pada bulan Agustus 2020.

Besar sampel minimal yang dibutuhkan dalam penelitian adalah sebanyak 81 sampel. Yang termasuk dalam sampel penelitian adalah bayi yang dirawat di Ruang Perinatologi RSUD Wangaya sejak bulan Januari 2019 hingga bulan Agustus 2020 serta memenuhi kriteria inklusi dan eksklusi. Kriteria inklusi adalah pasien bayi berusia 0-28 hari yang dirawat di Ruang Perinatologi RSUD Wangaya dengan kecurigaan adanya sepsis neonatorum. Kriteria eksklusi adalah bayi yang dirawat di Ruang Perinatologi RSUD Wangaya dengan riwayat penyakit hematologi, kelainan bawaan, penyakit autoimun, imunodefisiensi, dan data rekam medis yang tidak lengkap. Pengambilan sampel dilakukan dengan teknik konsekutif (consecutive sampling), data pasien diperoleh melalui buku register Ruang Perinatologi RSUD

\section{Tabel 1. Karakteristik sampel penelitian pasien diare}

\begin{tabular}{lcc}
\multicolumn{1}{c}{ Karakteristik } & Frekuensi (N) & Persentase (\%) \\
\hline Umur (Bulan) & 14 & 38,9 \\
$6-12$ & 22 & 61,1 \\
$13-24$ & & \\
Jenis Kelamin & 21 & 58,3 \\
$\quad$ Laki-laki & 15 & 41,7 \\
$\quad$ Perempuan & 36 & 100 \\
\hline Total & 36 \\
\hline
\end{tabular}

Tabel 2. Nilai diagnosis MPV pada sepsis neonatorum

\begin{tabular}{lccccc}
\hline \multirow{2}{*}{ ASI Eksklusif } & \multicolumn{2}{c}{ Diare } & Total & p & $\begin{array}{c}\text { RP } \\
\text { (Cl 95\%) }\end{array}$ \\
\cline { 2 - 5 } & Diare & Tidak Diare & & & (CI \\
\hline ASI Eksklusif & 9 & 13 & 22 & 0,003 & 0,51 \\
Tidak ASI Eksklusif & 27 & 7 & 34 & & $(0,005-0,589)$ \\
\hline Total & 36 & 20 & 56 & & \\
\hline
\end{tabular}

`bermakna jika $p<0,05$

Wangaya dengan kecurigaan sepsis neonatorum selama periode Januari 2019 - Agustus 2020. Setelah itu data nilai MPV, diagnosis sepsis neonatorum, jenis kelamin, usia gestasi, berat lahir, metode persalinan, ketuban pecah dini, asfiksia, dan hasil kultur darah diambil melalui rekam medis pasien. Data yang sesuai dengan kriteria inklusi dan eksklusi akan dimasukkan sebagai sampel dan ditabulasi lalu dianalisa dengan analisis univariat dan analisis uji diagnostik menggunakan is receiver operating characteristic MPV dan kemudian menentukan itivitas, spesifisitas, nilai prediksi nilai prediksi negatif, serta akurasi program komputer Statistical Product and Service Solution (SPSS) 24 for Windows.

\section{HASIL}

Selama bulan Januari - Desember 2019 ditemukan lebih dari 100 anak berusia 6 - 24 bulan terdiagnosa diare dan juga penyakit lain yang dirawat di Ruang Kaswari RSUD Wangaya dan 56 orang diantaranya dijadikan sampel setelah memenuhi kriteria inklusi dan eksklusi penelitian (Tabel 1).

Dari total sampel penelitian sebanyak 56 sampel, yang terdiagnosa diare

\section{PEMBAHASAN}

Dari hasil penelitian tentang karakteristik subjek penelitian yang terdiagnosa diare berdasarkan rentang umur, ditemukan bahwa anak terdiagnosa dengan diare terbanyak pada rentang umur 13-24 bulan yaitu $61,1 \%$. Hal tersebut sesuai dengan hasil yang didapatkan dari penelitian Sabella dkk bahwa anak penderita diare terbanyakada dikelompokusia 12-59 bulan $(93,6 \%){ }^{13,14}$ Sehingga dapat disimpulkan bahwa diare lebih banyak terjadi pada anak umur diatas 1 tahun. Hal ini kemungkinan menyebabkan mudahnya balita usia tersebut memakan makanan telah yang terkontaminasi. Faktor higienitas alatalat makan dan kurangnya kebersihan makanan yang disiapkan oleh ibu juga dapat mempengaruhi hal tersebut. ${ }^{15}$ Selain itu, balita usia 12-59 bulan lebih aktif bergerak bila dibandingkan balita usia 0-11 bulan. Balita usia 12-59 bulan sudah mulai belajar berjalan, sehingga lebih aktif 
bermain di luar rumah dan seringkali tanpa pengawasan orang tua. Hal ini yang mengakibatkan pada usia tersebut lebih muda terpapar agen penyebab diare. ${ }^{15}$

Subjek dari penelitian ini yang memiliki jenis kelamin laki-laki ditemukan lebih banyak terdiagnosa diare bila dibandingkan dengan perempuan yaitu sebesar $58,3 \%$ dari total subjek. Hasil ini sejalan dengan penelitian oleh Sabella dkk yang menemukan balita lakilaki dengan diare lebih banyak (59,5\%) dibandingkan perempuan $(40,5 \%) .{ }^{14} \mathrm{Hal}$ ini tidak didukung dengan penelitian oleh Yusuf dkk yang menemukan balita perempuan lebih banyak yang terkena diare (51,9\%) dibandingkan laki-laki $(48,1 \%) .{ }^{16}$ Penelitian oleh Purba dkk mendapatkan hasil bahwa tidak ada hubungan yang signifikan antara jenis kelamin dengan kejadian diare pada balita. ${ }^{17}$ Beberapa penelitian lainnya mencantumkan bahwa walau terdapat beberapa perbedaan angka diare pada balita laki-laki maupun perempuan, tidak ditemukan perbedaan yang signifikan sehingga dapat disimpulkan jenis kelamin tidak mempengaruhi kejadian diare..$^{16,17}$

Pada penelitian ini ditemukan angka kejadian diare pada anak yang tidak mendapat ASI eksklusif lebih tinggi (75\%) dibandingkan dengan anak yang mendapat ASI eksklusif (25\%). Hal tersebut sejalan dengan penelitian Maretha dkk yang mendapatkan hasil penelitian yang dilakukan, diketahui bahwa kelompok yang mendapat ASI eksklusif berpeluang sebesar $92,1 \%$ untuk tidak mengalami diare. Peluang bayi yang mendapat ASI eksklusif untuk mengalami diare hanya sebesar $4 \% .{ }^{13}$ Penelitian lain yang mendukung adalah penelitian yang dilakukan oleh Wijayanti yang juga menemukan adanya hubungan yang signifikan antara pemberian ASI eksklusif dengan kejadian diare. ${ }^{18}$ Menurut Newburg dkk oligosakarida merupakan faktor yang terutama berperan dalam melindungi bayi dari kuman patogen di saluran cerna. Oligosakarida juga diketahui berperan dalam menghambat toksin stabil baik secara in vivo atau pun in vitro. Ada berbagai efek protektif yang dimiliki oleh ASI yang terdiri atas IgA, leukosit, dan beberapa faktor protektif non spesifik seperti enzim lisozim, laktoferin, nukleotida dan sebagainya. ${ }^{19}$ Menurut Lamberti dkk terdapat 2 efek protektif yang ditimbulkan ASI terhadap diare yaitu dapat menurunkan insiden diare dan berpengaruh terhadap lamanya diare. Dalam hal ini, Lamberti membandingkan efek perlindungan dari masing-masing pola pemberian ASI, dimana ditemukan bahwa ASI eksklusif adalah yang terbaik bagi bayi. ASI eksklusif memiliki efek perlindungan yang lebih baik dibandingkan ASI parsial ataupun predominan..$^{20}$

Keterbatasan penelitian ini adalah subjek dalam penelitian jumlahnya sedikit karena waktu dalam pengumpulan sampel yang cukup singkat. Selain itu karena desain penelitian ini menggunakan studi cross-sectional, dimana pengambilan data faktor risiko dan penyakit yang ditimbulkan dilakukan pada satu saat yang bersamaan, maka peneliti sulit untuk mengontrol secara langsung variabelvariabel perancu lainnya yang mungkin dapat mempengaruhi kejadian diare pada anak.

\section{SIMPULAN}

Terdapat hubungan yang bermakna antara status ASI eksklusif dengan angka kejadian diare pada anak usia 6 - 24 bulan di RSUD Wangaya. Anak yang mendapat ASI eksklusif memiliki risiko mengalami diare yang lebih rendah yaitu 0,51 kali apabila dibandingkan dengan anak yang tidak mendapat ASI eksklusif.

\section{KONFLIK KEPENTINGAN}

Tidak terdapat konflik kepentingan dalam penulisan laporan penelitian ini.

\section{PENDANAAN}

Penelitian ini dilakukan tanpa adanya bantuan dari sponsor atau sumber pendanaan lainnya.

\section{KONTRIBUSI PENULIS}

Seluruh penulis memilki kontribusi yang sama dalam penulisan laporan hasil penelitian ini baik dari tahap penyusunan proposal, pencarian data, analisis data, interpretasi data, dan penyajian laporan akhir.

\section{ETIKA PENELITIAN}

Penelitian ini telah memenuhi syarat kelaikan etik dari Komisi Etik Peneltian Kesehatan RSUD Wangaya Denpasar (No. 070/ 1423/ RSUDW).

\section{DAFTAR PUSTAKA}

1. World Health Organization. Diarrhoeal disease [Internet]. WHO. 2020 https://www.who.int/ en/news-room/fact-sheets/detail/diarrhoealdisease

2. Kementerian Kesehatan Republik Indonesia. Riset Kesehatan Dasar (RISKESDAS). Jakarta: Balitbang Kemenkes RI. 2013.

3. Kementerian Kesehatan Republik Indonesia. Riset Kesehatan Dasar (RISKESDAS). Jakarta: Balitbang Kemenkes RI. 2008.

4. Kementerian Kesehatan Republik Indonesia. Riset Kesehatan Dasar (RISKESDAS). Jakarta: Balitbang Kemenkes RI. 2018.

5. Thiagarajah, Jay R. et al. Advances in Evaluation of Chronic Diarrhea in Infants Gastroenterology, Volume 154. Issue 8. 2018. p2045 - 2059. doi:10.1053/j.gastro.2018.03.067.

6. Radlović N, Leković Z, Vuletić B, Radlović V, Simić D. Acute Diarrhea in Children. Srp Arh Celok Lek. 2015. 143(11-12):755-762. doi:10.2298/sarh1512755r

7. Wardlaw T, Salama P, Brocklehurst C, Chopra M, Mason E. Diarrhoea: why children are still dying and what can be done. Lancet. 2010;375(9718):870-872. doi:10.1016/S01406736(09)61798-0.

8. Kramer MS, Kakuma R. Optimal duration of exclusive breastfeeding. Cochrane Database Syst Rev. 2012;2012(8):CD003517. Published 2012 Aug 15. doi:10.1002/14651858.CD003517. pub2.

9. Kuchenbecker J, Jordan I, Reinbott A, et al. Exclusive breastfeeding and its effect on growth of Malawian infants: results from a cross-sectional study. Paediatr Int Child Health. 2015;35(1):14-23. doi:10.1179/204690551 4Y.0000000134.

10. Martin CR, Ling PR, Blackburn GL. Review of Infant Feeding: Key Features of Breast Milk and Infant Formula. Nutrients. 2016;8(5):279. Published 2016 May 11. doi:10.3390/ nu8050279.

11. Soto A, Martín V, Jiménez E, Mader I, Rodríguez JM, Fernández L. Lactobacilli and bifidobacteria in human breast milk: influence of antibiotherapy and other host and clinical factors. J Pediatr Gastroenterol Nutr. 2014;59(1):78-88. doi:10.1097/ MPG.0000000000000347.

12. Lubiech $\mathrm{K}$ and Twaruzek M. Lactobacillus bacteria in breast milk. Nutrients. 2020. (12);3783. P1-13. doi:10.3390/nu12123783

13. Hanieh S, Ha TT, Simpson JA, et al. Exclusive breast feeding in early infancy reduces the risk of inpatient admission for diarrhea and suspected pneumonia in rural Vietnam: a prospective cohort study. BMC Public Health. 2015;15:1166. Published 2015 Nov 24. doi:10.1186/s12889-015-2431-9. 
14. Sabella GV, Maya S, Dewi A. karakteristik pada balita diare dengan infeksi enteropathogenic escherichia coli (EPEC) di Puskesmas rawat inap Kota Pekanbaru. JOM FK. Vol 2. No 1. 2015. p1-7.

15. Florez ID, Niño-Serna LF, Beltrán-Arroyave CP. Acute Infectious Diarrhea and Gastroenteritis in Children. Curr Infect Dis Rep. 2020;22(2):4. Published 2020 Jan 28. doi:10.1007/s11908020-0713-6.

16. Yusuf S. Profil Diare di Ruang Rawat Inap Anak. Sari Pediatri. 2016. Vol 13. Edisi 4. p265-270. doi:10.14238/sp13.4.2011.265-70.

17. Purba EM. Faktor-faktor yang Berhubungan dengan Kejadian Diare pada Anak Balita di
Wilayah Kerja Puskesmas Matiti Kecamatan Doloksanggul Kabupaten Humbang Hasundutan Tahun 2012. USU. 2012.

18. Wijayanti W. Hubungan antara pemberian ASI eksklusif dengan kejadian diare pada bayi umur 06 bulan di Puskesmas Gilingan Kecamatan Banjarsari Surakarta. USM. 2010

19. Newburg DS, Ruiz-Palacios GM, Altaye M, et al. Innate protection conferred by fucosylated oligosaccharides of human milk against diarrhea in breastfed infants [published correction appears in Glycobiology. 2004 May;14(5):13G]. Glycobiology. 2004;14(3):253263.
20. Lamberti LM, Fischer Walker CL, Noiman A, Victora C, Black RE. Breastfeeding and the risk for diarrhea morbidity and mortality. BMC Public Health. 2011;11 Suppl 3(Suppl 3):S15. Published 2011 Apr 13. doi:10.1186/1471-245811-S3-S15

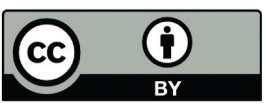

This work is licensed under a Creative Commons Attribution 